\title{
Overlapping Repair in Patients with Anal Sphincter Injury
}

\author{
Sezai Demirbas ${ }^{a}$ Vedat Atay ${ }^{b} \quad$ Ilker Sucullua A. Ilker Filiz ${ }^{a}$ \\ Departments of a General Surgery and ${ }^{\mathrm{b}}$ Obstetrics and Gynecology, GATA Haydarpasa Training Hospital, \\ Istanbul, Turkey
}

\section{Key Words}

Anal sphincter injury $\cdot$ Fecal incontinence $\cdot$ Overlap

sphincter repair

\begin{abstract}
Objective: The aim of this study was to demonstrate the improvement of anal canal function after overlap sphincter repair and confirm that this treatment option is superior in patients with nonobstetric sphincter damage. Subjects and Methods: From 1998 to 2003, 44 women who underwent overlapping sphincter repair were enrolled in this study. The women were allocated to one of two groups, obstetric trauma $(n=31)$ and nonobstetric (perineal) trauma $(n=13)$. Both groups were compared in terms of age, operation time, number of deliveries, hospital stay, need for analgesics, complication rate, pre- and postoperative outcomes of anal manometry and quality of life, using the fecal incontinence severity index and a questionnaire for fecal disorders. Results: Anal canal length was significantly extended postoperatively in both groups compared to preoperative length. Eightweek postoperative resting and squeeze pressures were significantly higher than preoperative pressures in both patients with nonobstetric and obstetric sphincter injury. Although significant increase was seen in both groups, the mean postoperative resting and squeeze pressures at 1 year were rather high in patients with nonobstetric sphincter injury. At the end of a year of follow-up, overall satisfaction of the repair
\end{abstract}

\section{KARGER}

Fax +4161306 1234

E-Mail karger@karger.ch

www.karger.com
(C) 2007 S. Karger AG, Basel

1011-7571/08/0171-0056\$24.50/0

Accessible online at:

www.karger.com/mpp was about $82 \%$. Conclusion: Overlap sphincter repair was feasible, although patient satisfaction was slightly less in the obstetric than in the nonobstetric trauma group. The improvement of anal function at 20- to 24-month follow-up is attributed to both high squeeze pressure and broad anal canal.

Copyright $\odot 2007$ S. Karger AG, Basel

\section{Introduction}

Fecal incontinence is a socially disabling disorder, and its prevalence is about $2-15 \%$ in adults [1], but in elderly women over 85 years, prevalence is approximately $17 \%$ [2]. The major cause of fecal incontinence is anal sphincter injury that occurs during vaginal delivery, particularly when forceps have been used [3]. Equally important, it could also be due to previous perianal surgery and pelvic trauma. Fecal incontinence significantly affects a patient's life. Anal sphincter repair can reestablish continence and improve the quality of life for the patient [4-6]. Overlapping sphincter repair is defined as a repair procedure for anal sphincter injury due to obstetric trauma [4-7]. The operative technique was first described by Parks and McPartlin [7] in 1971 and subsequently was modified by Slade et al. [5] in 1977. The procedure is the one most frequently performed by colon and rectal surgeons in recent decades for treatment of fecal inconti- 
nence; however, recent reports have stated that the outcome of overlapping sphincter repair in patients with obstetric injury is seldom perfect in the long term [8]. The aim of this study was to evaluate the efficacy of overlapping sphincter repair in both obstetric and nonobstetric sphincter damage.

\section{Subjects and Methods}

In this study, 44 women presenting with fecal incontinence who underwent overlapping repair from 1998 to 2003 were enrolled in two groups: obstetric trauma group $(\mathrm{OTG}, \mathrm{n}=31)$ and nonobstetric trauma group (NTG, $\mathrm{n}=13$ ). The OTG had obstetric sphincter injury due to second- to third-degree laceration during delivery. The NTG had the following perianal surgical procedures: hemorrhoidectomy, $\mathrm{n}=4$; perianal fistulas, $\mathrm{n}=6$ ( 1 out of 6 for Crohn's disease); traumatic injuries and sexual abuse, $n=2$, and previously repaired sphincter, $\mathrm{n}=1$. Physical examination, digital rectal and rectosigmoidoscopic examination were performed initially. Pre- and postoperative incontinence status was evaluated by the fecal incontinence severity index (FISI) scoring system. Anal manometric measurements were performed in the patients with FISI more than 6 to define the severity of the incontinence status. Preoperative endoanal ultrasonography (EUS) was performed for each patient to define internal anal sphincter (IAS) and external anal sphincter (EAS) location and alteration of continuity. Patients had a follow-up examination at 8 weeks and then annually. The validated quality-of-life questionnaire SF-36 for fecal disorders was administered to each patient 12 and 24 months after surgery. A detailed consent form and required information were given before each procedure, such as anal manometry, EUS and surgery.

\section{Anal Canal Function}

The continence status was evaluated with the FISI scoring system [9]. Pre- and postoperative anal manometry was done using a six-channel, flexible, withdrawal water-perfused catheter (Albyn Medical, Mui Scientific, Mississauga, Ont., Canada) in all patients with a FISI score greater than 6 . The functional anal canal length was defined as the length of high pressure zone, where the pressure was at least $20 \mathrm{~mm} \mathrm{Hg}$ higher than the mean resting pressure.

\section{Endoanal Ultrasonography}

EUS was performed with a 360-degree rotating built-in 10$\mathrm{MHz}$ ultrasonic probe (B\&K Medical, Denmark) and a built-in $16-\mathrm{MHz}$ rectal probe. IAS, EAS, and any defect in anal sphincter were carefully imaged. The ends of the defect of the EAS were carefully defined. EUS was performed for all patients preoperatively, and 8 weeks after overlapping sphincter repair for 5 selected patients with FISI still above 6-8.

\section{Assessment of Anal Functional Outcome}

The condition of anal function in the patients was evaluated by using the validated quality-of-life questionnaire for fecal incontinence (QoL-FI, SF-Short Form-36) preoperatively and a year after surgery.

Overlap Repair for Anal Injury

\section{Operative Technique}

Mechanical bowel cleansing was performed the day before surgery and metronidazole (Ornidazole ${ }^{\circledR}$; Roche, Istanbul, Turkey) $0.8 \mathrm{~g}$ /day was given $2 \mathrm{~h}$ before surgery and continued for 5 days. After spinal or caudal anesthesia, each patient was placed in a jackknife position. Prepared 1/200,000 epinephrine solution was injected beneath the anodermal mucosa. A near-curvilinear incision $1 \mathrm{~cm}$ from the anodermal junction was made around the anal orifice. After the anoderm was lifted, both ends of the EAS and surrounding fatty tissue were mobilized sufficiently to make one edge of the EAS overlap the other. The scar was not removed. Overlapping repair with good bulk of both ends of the EAS was performed by using 2/0 nylon sutures (Ethicon Endo-Surgery, Inc., Cincinnati, Ohio, USA).

\section{Pain Management}

The usual scheme for analgesia was utilized. Pethidine $\mathrm{HCl}$, $1 \mathrm{mg} / \mathrm{kg} /$ day (Aldolan ${ }^{\circledR}$ flc. $100 \mathrm{mg} / 2 \mathrm{ml}$; Liba, Turkey), was injected intramuscularly in the first 2 postoperative hours. A nonsteroidal anti-inflammatory drug (ibuprofen IBU-600; Yeni Ilac, Istanbul, Turkey), $600 \mathrm{mg} / \mathrm{twice}$ daily, was prescribed from postoperative day 1 perorally. The severity of postoperative pain was assessed at 2, 4, 8, 16 and $36 \mathrm{~h}$ after surgery.

\section{Statistical Analysis}

Wilcoxon's signed-rank test was performed for paired samples while independent variables between two groups were evaluated by using Mann-Whitney U test for data analyses. Statistical significance assigned to any $\mathrm{p}$ value was $\leq 0.05$.

\section{Results}

The demographics of the patients are given in table 1 . Operating time was longer in OTG $(71.3 \pm 18.8 \mathrm{~min})$ than NTG (55.4 $\pm 22.5 \mathrm{~min})$ and the difference was statistically significant $(\mathrm{p}=0.02)$. Vaginal delivery was more frequent in OTG (2.8) than NTG (1.4) and no patient needed narcotic analgesics. Follow-up was similar in both groups of patients; 42 (95.4\%) of them were discharged $36 \mathrm{~h}$ after surgery. VAS score on postoperative days 1 and 2 was 3.1 (range 1-6) and 0.7 (range 0-2), respectively. Sphincter defect by EUS was demonstrated in 30 patients $(68.2 \%)$. Although all 30 patients had EAS defects to different degrees, 17 out of $30(56.6 \%)$ also had IAS rupture. Of the 44 patients, 7 (16\%) experienced keyhole deformity, 4 (1.0\%) had repair failures by the end of a year, and 3 of them were in the OTG. They were reoperated, and overlapping sphincter repair was employed again. Of the 44 patients, 5 (11.4\%) had early complications: bleeding, $\mathrm{n}=3$ in OTG; urinary infection, $\mathrm{n}=1$, and postoperative perianal fistula in NTG.

In the OTG and NTG, mean minimal resting pressure increased from 21.2 to $35.2 \mathrm{~mm} \mathrm{Hg}(\mathrm{z}=5.779, \mathrm{p}<0.001)$ and from 26.8 to $45 \mathrm{~mm} \mathrm{Hg}(\mathrm{z}=5.783, \mathrm{p}<0.001)$, respec- 
Table 1. Demographics of patients with obstetric and nonobstetric trauma

\begin{tabular}{lcc}
\hline & Obstetric trauma & Nonobstetric trauma \\
\hline Number & 31 & 13 \\
Age, years & $29.3 \pm 6.1(22-47)$ & $26.6 \pm 5.6(20-39)$ \\
Operation time, min & $71.3 \pm 18.8(45-110)$ & $55.4 \pm 22.5(45-75)$ \\
Vaginal deliveries & $2.8(0-5)$ & $1.4(0-3)$ \\
Hospital stay, days & $1.5(1-7)$ & $1.4(1-9)$ \\
Follow-up, months & $20.2 \pm 11.8(10-65)$ & $24.6 \pm 16.3(8-60)$ \\
Failures in a year & 3 & 1 \\
\hline
\end{tabular}

Table 2. Outcome of anal manometry in patients of both groups (mean $\pm \mathrm{SD}$; min-max in parentheses)
Table 3. Outcome of FISI scores in patients with failure and success rates

\begin{tabular}{lccc}
\hline Manometry results & Preoperatively & 8 weeks postoperatively & $\mathrm{p}$ \\
\hline OTG & & & \\
MRP, mm Hg & $21.2 \pm 3.4(12-33)$ & $35.2 \pm 2.2(27-39)$ & $<0.001$ \\
MSP & $44 \pm 3.1(33-50)$ & $59.8 \pm 3.1(53-71)$ & $<0.001$ \\
Anal canal length, cm & $1.18 \pm 0.7$ & $3 \pm 0.3$ & 0.0068 \\
\hline NTG & & & $<0.001$ \\
MRP, mm Hg & $26.8 \pm 3.5(17-41)$ & $45 \pm 1.8(39-351)$ & $<0.001$ \\
MSP & $51.6 \pm 3.6(40-62)$ & $77 \pm 4.7(55-90)$ & 0.007 \\
Anal canal length, cm & $2.1 \pm 0.6$ & $3.4 \pm 0.7$ & \\
\hline
\end{tabular}

$\mathrm{MRP}=$ Minimal resting pressure; $\mathrm{MSP}=$ maximal squeeze pressure.

\begin{tabular}{llll}
\hline \multicolumn{2}{c}{ FISI score } & & \\
\cline { 2 - 4 } & preoperatively & $\begin{array}{l}\text { 8 weeks } \\
\text { postoperatively }\end{array}$ & $\begin{array}{l}12 \text { months } \\
\text { postoperatively }\end{array}$ \\
\hline OTG & $\begin{array}{l}18 \\
\text { NTG }\end{array}$ & $\begin{array}{l}19(9.7 \%) \\
(\mathrm{n}=31)\end{array}$ & $\begin{array}{l}18(16 \%) \\
(\mathrm{n}=5) \\
16(23 \%) \\
(\mathrm{n}=3)\end{array}$ \\
\hline Success rate, $\%$ & $(\mathrm{n}=13)$ & $(13.3 \%)$ & 82 \\
\hline $\mathrm{n}=$ Number of subjects. & & 88.6 & \\
\hline
\end{tabular}

tively. Maximum squeezing pressure improved from 44 to $59.8 \mathrm{~mm} \mathrm{Hg}(\mathrm{z}=5.780, \mathrm{p}<0.001)$ and from 51.6 to 77 $\mathrm{mm} \mathrm{Hg}(\mathrm{z}=5.778, \mathrm{p}<0.001)$ in OTG and NTG, respectively (table 2). Postoperative outcome of both minimal resting pressure and maximal squeeze pressure were notably better in NTG than OTG $(\mathrm{z}=5.103, \mathrm{p}<0.001$; $\mathrm{z}=$ $4.429, \mathrm{p}<0.001)$. An anal canal length of about $3 \mathrm{~cm}$ was significantly broader in both groups at the end of the second month postoperatively $(\mathrm{p}=0.007)$.
Preoperatively, all patients in both the OTG and NTG had incontinence (FISI score of 18, table 3). Eight weeks after surgery, 3 patients in OTG and 2 patients in NTG had a FISI score of 19 and 17, respectively. However, 8 patients in both groups had incontinence with FISI of about 18 and 16 a year after repair. The remaining 36 patients (26 in OTG and 10 in NTG) had almost normal control of bowel function. 
Of the 44 patients, 8 (18\%) had poor anorectal function 1 year after surgery while the remaining $36(82 \%)$ had moderate to perfect function: moderate, $\mathrm{n}=9$ (20.4\%); good, $\mathrm{n}=17$ (36.3\%), and perfect, $\mathrm{n}=10(22.7 \%)$. However, at the end of 2 years, the subgroup with poor anorectal function increased to 12 patients (21.3\%); perfect function decreased to 6 patients (13.6\%), while 17 (38.6\%) reported good and 15 (34.1\%) moderate function.

\section{Discussion}

End-to-end sphincter repair was the most widely used procedure before the 1940s. Because of high failure, surgeons had a tendency to perform overlapping sphincter repair for patients with anal sphincter injury, which improved the success rate [10]. Overlapping repair results in better anal function because the surface area is thick, thereby widening the anal canal $[11,12]$. Several investigators $[10,13,14]$ have reported an overlapping repair success rate of $71 \%$, in which there was a significant improvement in patient's bowel control.

The increases in mean maximal squeeze pressure and mean anal sphincter length of our study are similar to those from previous studies $[11,12,15,16]$. The increased mean maximal squeeze pressure after overlapping sphincter repair is related to the improvement in continence and is the only parameter significant in anal manometry. Moreover, Ha et al. [11] reported that there was a trend towards more complete continence in patients with nonobstetric compared with obstetric injury, although this did not show statistical significance.

The improvement of anal functions in patients who underwent overlapping repair at the age of 50 is not clear. Although some reports $[17,18]$ suggested that there was no correlation between age and postoperative function, another concluded that failure rates were higher with increasing age [13]. Pudendal nerve terminal motor latency (PNTML) was considered to be an important factor in determining the poor outcome of overlapping sphincter repair, which was recognized by Tjandra et al. [10] in their series [19-21]. However, other studies [13, 14] noted that PNTML might not be sensitive enough to detect nerve damage, and PNTML time was delayed for each woman even after the first vaginal delivery [21-23]. Tetzschner et al. [24] report that reliability of PNTML depended on several factors such as the measurements performed, time of day, and side of the nerve used. Thus, it is difficult to conclude that delayed PNTML is the main factor causing anal incontinence in multiparous women.

Halverson and Hull [8] evaluated the quality of life for patients undergoing overlapping sphincter repair over a long follow-up period using the ASCRS (American Society of Colon and Rectal Surgeons)-validated FISI and quality of life scale [9]. They recorded a close correlation between a low FISI score and high quality of life for the patient.

In this study, the continence function of the anal canal was evaluated with the FISI scoring system, covering both the severity and frequency of the complaints [9]. The patient's continence improved to $88.6 \%$ at 8 weeks postoperatively. At the end of a year, 36 patients $(82 \%)$ had total continence and $8(18 \%)$ had a high-ranking FISI score. Both NTG and OTG groups had some failure (18\%). Because the pre- and postoperative mean resting and squeeze pressures of nonobstetric sphincter injury patients were significantly higher than those of the obstetric sphincter injury group, NTG should have delayed sphincter repair, while the patients with obstetric injury could have the repair done at the time of delivery. This recommendation is based on the fact that during the operation, the bulky sphincter muscles with scar tissue give an opportunity to make a clear dissection and thicker overlap repair without bleeding. In patients with obstetric sphincter rupture, scar tissue is not as thick as in patients with nonobstetric trauma so that the overlapping repair formed is thinner. These factors could be the reason why higher resting and squeeze pressure and good continence in follow-up were significant in the NTG.

\section{Conclusion}

This study confirms that overlap sphincter repair is feasible for patients with both obstetric sphincter tear and perianal trauma. Patient satisfaction was slightly less in OTG than NTG. Overlap repair should be employed for OTG patients after delivery for better quality of life.

References

\footnotetext{
1 MacMillan AK, Merrie AE, Marshall RJ, Parry BR: The prevalence of fecal incontinence in community-dwelling adults: a systematic review of the literature. Dis Colon Rectum 2004;47:1341-1349.

$\checkmark 2$ Hellstrom L, Ekelund P, Milsom I, Skoog I: The influence of dementia on the prevalence of urinary and faecal incontinence in 85 year-old men and women. Arch Gerontol Geriatr 1994;19:11-20.
} 
3 Christianson LM, Bovbjerg VE, McDavitt EC, Hullfish KL: Risk factors for perineal injury during delivery. Am J Obstet Gynecol 2003; 189:255-260.

$\checkmark 4$ Cook TA, Mortensen NJ: Management of faecal incontinence following obstetric injury. Br J Surg 1998;85:293-299.

$>5$ Slade MS, Goldberg SM, Schottler JL, Balcos EG, Christenson SE: Sphincteroplasty for acquired anal incontinence. Dis Colon Rectum 1977;20:33-35.

6 Fang DT, Nivatvongs S, Vermeulen FD, Herman FN, Golgberg SM, Rothenberger DA: Overlapping sphincteroplasty for acquired anal incontinence. Dis Colon Rectum 1984; 27:720-722.

7 Parks AG, McPartlin JF: Late repair of injuries of the anal sphincter. Proc R Soc Med 1971;64:1187-1189.

$>8$ Halverson AL, Hull TL: Long-term outcome of overlapping anal sphincter repair. Dis Colon Rectum 2002;45:345-348.

$>9$ Rockwood TH, Church JM, Fleshman JW, Kane RL, Mavrantonis C, Thorson AG, Wexner SD, Bliss D, Lowry AC: Patient and surgeon ranking of the severity of symptoms associated with fecal incontinence: the fecal incontinence severity index. Dis Colon Rectum 1999;42:1525-1532.

10 Tjandra JJ, Han WR, Goh J, Carey M, Dwyer $\mathrm{P}$ : Direct repair vs. overlapping sphincter repair. Dis Colon Rectum 2003;46:937-943.
11 Ha HT, Fleshman JW, Smith M, Read TE, Kodner IJ, Birnbaum EH: Manometric squeeze pressure difference parallels functional outcome after overlapping sphincter reconstruction. Dis Colon Rectum 2001;44: 655-660.

$>12$ Wexner SD, Marchetti F, Jagelman DG: The role of sphincteroplasty for fecal incontinence reevaluated: a prospective physiologic and functional review. Dis Colon Rectum 1991;34:22-30.

13 Sitzler PJ, Thompson JP: Overlap repair of damaged anal sphincter: a single surgeon's series. Dis Colon Rectum 1996;39:13561360

$>14$ Malouf AJ, Norton CS, Engel AF, Nichols RJ, Kamm MA: Long-term results of overlapping anterior anal-sphincter repair for obstetric trauma. Lancet 2000;355:260-265.

15 Fleshman JW, Dreznik Z, Fry RD, Kodner IJ Anal sphincter repair for obstetric injury: manometric evaluation of functional results Dis Colon Rectum 1991;34:1061-1067.

16 Londono-Schimmer EE, Garcia-Duperly R, Nichols RJ, Ritchie JK, Hawley PR, Thompson JP: Overlapping anal sphincter repair for faecal incontinence due to sphincter trauma: five year follow up functional results. Int J Colorect Dis 1994;9:110-113.

17 Oliveira L, Pfeifer J, Wexner SD: Physiological and clinical outcome of anterior sphincteroplasty. Br J Surg 1996;83:502-505.
8 Young CJ, Mathur MN, Eyers AA, Solomon MJ: Successful overlapping anal sphincter repair: relationship to patient age, neuropathy and colostomy formation. Dis Colon Rectum 1998;41:344-349.

19 Sangwan YP, Coller JA, Barrett RC, Murray JJ, Roberts PL, Schoetz DJ Jr: Unilateral pudental neuropathy: impact on outcome of anal sphincter repair. Dis Colon Rectum 1996;39:686-689.

20 Ctercteko GC, Fazio VW, Jagelman DG, Lavery IC, Weakley FL, Melia M: Anal sphincter repair: a report of 60 cases and review of the literature. Aust N Z J Surg 1988;58:703-710.

-21 Fynes M, Donnelly V, Behan M, O'Connell PR, O’Herlihy C: Effect of second vaginal delivery on anorectal physiology and faecal continence: a prospective study. Lancet 1999; 354:983-986

22 Leroi AM, Kamm MA, Weber J, Denis P, Hawley PR: Internal anal sphincter repair. Int J Colorect Dis 1997;12:243-245.

23 Gilliland R, Altomare DF, Moreira H Jr, Oliveira L, Gilliland JE, Wexner SD: Pudendal neuropathy is predictive of failure following anterior overlapping sphincteroplasty. Dis Colon Rect 1998;41:1516-1522.

24 Tetzschner T, Sorensen M, Rasmussen OO, Lose G, Christiansen J: Reliability of pudendal nerve terminal motor latency. Int J Colorectal Dis 1997;12:280-284. 